\title{
Editorial for the Special Issue: Clostridium difficile
}

\author{
Łukasz M. Grześkowiak (D)
}

check for

updates

Citation: Grześkowiak, Ł.M. Editorial for the Special Issue: Clostridium difficile. Microorganisms 2021, 9, 368. https://doi.org/ $10.3390 /$ microorganisms 9020368

Received: 3 February 2021

Accepted: 12 February 2021

Published: 12 February 2021

Publisher's Note: MDPI stays neutral with regard to jurisdictional claims in published maps and institutional affiliations.

Copyright: (C) 2021 by the author. Licensee MDPI, Basel, Switzerland. This article is an open access article distributed under the terms and conditions of the Creative Commons Attribution (CC BY) license (https:/ / creativecommons.org/licenses/by/ $4.0 /)$.
Institute of Animal Nutrition, Freie Universität Berlin, Königin-Luise-Str. 49, 14195 Berlin, Germany; lukasz.grzeskowiak@fu-berlin.de

Clostridium difficile (reclassified as Clostridioides difficile [1]), first described 85 years ago as a commensal microorganism in the feces of a newborn infant, has drawn further attention due to its involvement in intestinal infection that lead to high morbidity and mortality among individuals of different ages in healthcare and the community. It has also emerged as a zoonotic pathogen since highly genetically similar $C$. difficile isolates were characterized in humans, pets and farm animals [2,3]. Indeed, livestock can serve as a potential reservoir for $C$. difficile and pose a threat to humans since the spores facilitate the rapid spread of this bacterium in the environment. Although antimicrobial resistance is common among C. difficile [4], widespread antibiotic use in healthcare and animal husbandry has led to the development of multiresistant types, making the treatment of $C$. difficile infections (CDI) even more difficult [5]. Moreover, due to its anaerobic metabolism and relatively slow growth compared with other bacterial pathogens, research on $C$. difficile faces many challenges. However, in recent decades, significant advances in molecular methods has made possible a better understanding of the physiology and epidemiology of $C$. difficile in animals and humans $[4,6,7]$.

C. difficile is one of the pioneer microbial colonizers in animals and humans. In farm animals such as pigs, an immature yet developing microbiota allows for the outgrowth of C. difficile, including toxigenic types, which may lead to infection [8,9]. It is noteworthy that concentrations of $C$. difficile and its toxins in neonatal piglets peak quickly during the first week and diminish from the second week onwards [9]. Therefore, a very short time window for $C$. difficile colonization, including toxin-producing types, can be observed. Such an observation is also true for infants. However, the lack of toxin-receptor expression or toxin-neutralizing antibodies at such early age has been suggested as a reason that infants are protected against CDI development [10]. On the other hand, in adult humans C. difficile outgrowth and infections have been associated with microbial dysbiosis in the gut caused by comorbidities, the use of antimicrobials or advanced age [11,12]. Recently, it has been suggested that a decreased expression of the High Mobility Group Box 1 HMGB1 cytokine in peripheral blood is involved in the diminished capability of elderly patients with CDI to fight the pathogen [7]. Indeed, reports show that microbial diversity is decreased in both C. difficile-colonized and CDI patients, and certain bacteria have been identified as playing a key role in colonization resistance against $C$. difficile and CDI development $[13,14]$.

Lately, an in vitro study has demonstrated that sow colostrum, which contains antibodies against $C$. difficile toxins, may protect intestinal porcine cell lines from toxin-induced effects $[15,16]$. Moreover, the administration of antibodies against $C$. difficile toxins can protect all experimentally challenged piglets from developing systemic infection and minimize intestinal lesions [17]. Therefore, sufficient antibody titers against toxins transferred from mother to offspring through colostrum may be crucial in passive protection against gut intoxication and infection development once $C$. difficile colonization has been established in the piglet gut. In humans, clinical studies have identified protective antibodies against $C$. difficile toxins in the blood of patients who have suffered from CDI [18]. Further, a successful development of an antibody vaccine that neutralizes $C$. difficile toxin B has been demonstrated [19]. Finally, a recent study has identified a new immunoreactive surface protein isolated from $C$. difficile that is recognized by human blood and umbilical 
cord blood sera; therefore, it could serve a future use in preventive vaccine construction for humans [20].

The abovementioned studies demonstrate significant progress in the research on C. difficile. However, there are still many open questions regarding it, such as how healthy animal and human carriers of $C$. difficile and its toxins can remain free of symptoms or why there is a very short time window for colonization of $C$. difficile in certain farm animal species. Successful strategies to prevent and treat CDI in animals and humans while reducing the antimicrobial use are also needed.

Acknowledgments: Łukasz M. Grześkowiak was financially supported by the German Research Foundation (Deutsche Forschungsgemeinschaft, DFG) grant GR 5107/2-1. I would like to thank all the authors who contributed significantly to the Special Issue on Clostridium difficile. My gratitude goes to the reviewers for their valuable help in improving the manuscripts before being published. I would also like to thank the Assistant Editors for their excellent technical support in this Special Issue.

Conflicts of Interest: The author declares no conflict of interest.

\section{References}

1. Lawson, P.A.; Citron, D.M.; Tyrrell, K.L.; Finegold, S.M. Reclassification of Clostridium difficile as Clostridioides difficile (Hall and O'Toole 1935) Prévot 1938. Anaerobe 2016, 40, 95-99. [CrossRef] [PubMed]

2. Knetsch, C.W.; Connor, T.R.; Mutreja, A.; van Dorp, S.M.; Sanders, I.M.; Browne, H.P.; Harris, D.; Lipman, L.; Keessen, E.C.; Corver, J.; et al. Whole genome sequencing reveals potential spread of Clostridium difficile between humans and farm animals in the Netherlands, 2002 to 2011. Eurosurveillance [Online] 2014, 19, 20954. [CrossRef] [PubMed]

3. Bjöersdorff, O.G.; Lindberg, S.; Kiil, K.; Persson, S.; Guardabassi, L.; Damborg, P. Dogs are carriers of Clostridioides difficile lineages associated with human community-acquired infections. Anaerobe 2021. [CrossRef] [PubMed]

4. Masarikova, M.; Simkova, I.; Plesko, M.; Eretova, V.; Krutova, M.; Cizek, A. The colonisation of calves in czech large-scale dairy farms by clonally-related clostridioides difficile of the sequence type 11 represented by ribotypes 033 and 126 . Microorganisms 2020, 8, 901. [CrossRef] [PubMed]

5. Spigaglia, P.; Barbanti, F.; Mastrantonio, P.; Ackermann, G.; Balmelli, C.; Barbut, F.; Bouza, E.; Brazier, J.; Delmee, M.; Drudy, D.; et al. Multidrug resistance in European Clostridium difficile clinical isolates. J. Antimicrob. Chemother. 2011, 66, 2227-2234. [CrossRef] [PubMed]

6. Kachrimanidou, M.; Tzika, E.; Filioussis, G. Clostridioides (Clostridium) difficile in food-producing animals, horses and household pets: A comprehensive review. Microorganisms 2019, 7, 667. [CrossRef] [PubMed]

7. Czepiel, J.; Biesiada, G.; Pitera, E.; Wołkow, P.P.; Michalak, M.; Garlicki, A. Decreased expression of the high mobility group box 1 (HMGB1) gene in peripheral blood in patients with mild or moderate Clostridioides difficile infection. Microorganisms 2020, 8, 1217. [CrossRef] [PubMed]

8. Grześkowiak, Ł.; Dadi, T.H.; Zentek, J.; Vahjen, W. Developing Gut Microbiota Exerts Colonisation Resistance to Clostridium (syn. Clostridioides) difficile in Piglets. Microorganisms 2019, 7, 218. [CrossRef] [PubMed]

9. Grześkowiak, Ł.; Zentek, J.; Vahjen, W. Determination of the extent of Clostridium difficile colonisation and toxin accumulation in sows and neonatal piglets. Anaerobe 2016, 40,5-9. [CrossRef] [PubMed]

10. Jangi, S.; Lamont, J.T. Asymptomatic colonization by clostridium difficile in infants: Implications for disease in later life. J. Pediatr. Gastroenterol. Nutr. 2010, 51, 2-7. [CrossRef] [PubMed]

11. Jachowicz, E.; Wałaszek, M.; Sulimka, G.; Maciejczak, A.; Zieńczuk, W.; Kołodziej, D.; Karaś, J.; Pobiega, M.; Wojkowska-Mach, J. Long-term antibiotic prophylaxis in urology and high incidence of clostridioides difficile infections in surgical adult patients. Microorganisms 2020, 8, 810. [CrossRef] [PubMed]

12. Kachrimanidou, M.; Tsintarakis, E. Insights into the role of human gut microbiota in clostridioides difficile infection. Microorganisms 2020, 8, 200. [CrossRef] [PubMed]

13. Crobach, M.J.T.; Ducarmon, Q.R.; Terveer, E.M.; Harmanus, C.; Sanders, I.M.J.G.; Verduin, K.M.; Kuijper, E.J.; Zwittink, R.D. The bacterial gut microbiota of adult patients infected, colonized or noncolonized by clostridioides difficile. Microorganisms 2020, 8, 677. [CrossRef] [PubMed]

14. Buffie, C.G.; Bucci, V.; Stein, R.R.; McKenney, P.T.; Ling, L.; Gobourne, A.; No, D.; Liu, H.; Kinnebrew, M.; Viale, A.; et al. Precision microbiome reconstitution restores bile acid mediated resistance to Clostridium difficile. Nature 2015, 517, 205-208. [CrossRef] [PubMed]

15. Grześkowiak, Ł.; Pieper, R.; Kröger, S.; Martínez-Vallespín, B.; Hauser, A.E.; Niesner, R.; Vahjen, W.; Zentek, J. Porcine Colostrum Protects the IPEC-J2 Cells and Piglet Colon Epithelium against Clostridioides (syn. Clostridium) difficile Toxin-Induced Effects. Microorganisms 2020, 8, 142. [CrossRef] [PubMed]

16. Grześkowiak, Ł.M.; Pieper, R.; Huynh, H.A.; Cutting, S.M.; Vahjen, W.; Zentek, J. Impact of early-life events on the susceptibility to Clostridium difficile colonisation and infection in the offspring of the pig. Gut Microbes 2019, 10, 251-259. [CrossRef] [PubMed] 
17. Steele, J.; Mukherjee, J.; Parry, N.; Tzipori, S. Antibody against TcdB, but not TcdA, prevents development of gastrointestinal and systemic clostridium difficile disease. J. Infect. Dis. 2013, 207, 323-330. [CrossRef] [PubMed]

18. Shakir, F.A.; Ali, T.; Bigham, A.C.; Ballard, J.D.; Miner, P.B.; Philpott, J.R. Determination of serum antibodies to Clostridium difficile toxin B in patients with inflammatory bowel disease. Gastroenterol. Hepatol. (N. Y) 2012, 8, 313-317.

19. Alonso, C.D.; Mahoney, M.V. Bezlotoxumab for the prevention of clostridium difficile infection: A review of current evidence and safety profile. Infect. Drug Resist. 2019, 12, 1-9. [CrossRef] [PubMed]

20. Razim, A.; Pacyga, K.; Martirosian, G.; Szuba, A.; Gamian, A.; Myc, A.; Górska, S. Mapping epitopes of a novel peptidoglycan cross-linking enzyme Cwp22 recognized by human sera obtained from patients with Clostridioides difficile infection and cord blood. Microorganisms 2019, 7, 565. [CrossRef] [PubMed] 